DOI: https://doi.org/10.31392/NPU-nc.series9.2020.20.02

UDC: $811.521 ’ 37: 82.09: 001.4$

\author{
Lidiia S. Anistratenko \\ National Pedagogical Dragomanov University, \\ Kyiv, Ukraine
}

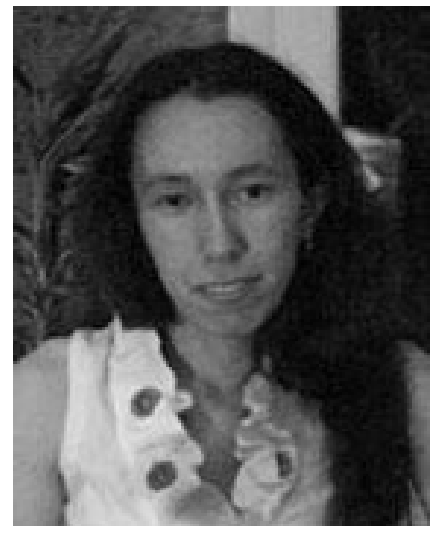

\title{
TEXTUAL FEATURES OF JAPANESE LITERARY TERMINOLOGY
}

\section{Bibliographic Description:}

Anistratenko, L. S. (2020). Textual Features of Japanese Literary Terminology. Scientific Journal of National Pedagogical Dragomanov University. Series 9. Current Trends in Language Development. 20. P. 16-32. https://doi.org/10.31392/NPU-nc.series9.2020.20.02

\section{Abstract}

This paper describes and systematizes the textual features of the professional language of Japanese literary studies, presented in the classic Japanese literary treatises. Based on the material of 17 treatises, a quantitative relationship between general literary vocabulary and literary terminology in professional texts of Japanese literary studies has been established; the percentage of supra-disciplinary, disciplinary and interdisciplinary literary terminology has been established; stylistic means adopted in the texts have been identified and analyzed; a comparative analysis of the written discourse of Japanese literary studies in diachrony has been carried out; the specific features of the texts of Japanese literary studies have been revealed.

Using the method of quantitative analysis, it has been established that the ratio of the use of literary terminology to the total amount of vocabulary in the text does not have a clear gradation in time but rather is a manifestation of the individual style of the author of the treatise. The average terminological saturation of professional texts in Japanese literary studies is $20 \%$. This indicator is considered low compared to the indicators of other disciplines.

The average indicator of terminological saturation of texts with individual analysed groups of terms, according to the results of the proposed study, is as follows: general scientific terminology - $18 \%$, interdisciplinary terminology $-8 \%$, terminology of other disciplines $-8 \%$, supra-disciplinary terminology - 15\%, disciplinary terminology $-51 \%$.

The percentage indicators of the terms of various disciplines of Japanese literary studies, including lyrics, epic, drama, lyric-epic, lyric-drama, folklore, have also been established. The predominance of terminological units in the discipline of lyrics $(62 \%)$ has been revealed. We maintain that the significant saturation of literary treatises with the lyrics terms is caused by the fact that the lyrics were considered high art for centuries throughout the history of Japanese literature.

Keywords: Japanese literary terminology, inter-disciplinary terminology, terminology of professional texts, disciplinary terminology, general scientific terminology. 


\section{Introduction.}

The study of textual features of terminology is relevant given that the term "exists, acts and often imperceptibly changes its semantics" in professional texts (Nikitina, 1987: 50). That is, professional discourse is a natural environment for the existence of a terminological unit, in contrast to lexicographic sources, where the term is in artificial conditions. It is commonly known that Japanese literary studies have a rich history (the first written works date back to the VIII century), during which new terminological units were enunciated. In our opinion, the study of terms in the literary treatises of Japanese classics will contribute to understanding not only the terminological features of Japanese literary studies but also the peculiarities of the mentality of the Japanese, whose world-view is reflected in the classical texts of professional literary studies.

\section{Literature Review.}

According to our data, as of today there are works devoted to the study of general issues of terminology of Japanese literary studies (Irwin, 2008; Lamarre, 2013; Laukik, 2015), certain terms of Japanese literary studies (Atkins, 2013; Moretti, 2010), analysis of terms of Japanese literary studies in lexicographic sources (Anistratenko, 2015; Anistratenko, 2016). However, we have no knowledge of a separate study on the functioning of terminological units in the professional texts of Japanese literary studies.

In the study of terminological vocabulary in professional texts of Japanese literary studies, we will use the developments of theorists of terminology as a science (Felber, 1980; Kyjak, 2009; Kvitko, 1987; Lejchik, 2007).

We will also rely on the previous experience of researchers of different terminology systems (Abakumova, 2011; Adylova, 2017; Duda, 2015; Madzhaeva 2011; Soljanenko, 2017; Syndegha 2009; 柳田國男, 1941).

\section{Aim and Objectives.}

The aim of the article is to comprehensively describe and systematize the textual features of Japanese classical literary terms.

This aim involves solving the following objectives:

- to establish the quantitative ratio of general literary vocabulary and literary terminology in professional texts of Japanese literary studies;

- to establish the percentage of supra-disciplinary, disciplinary and inter-disciplinary literary terminology;

- to identify and analyse the stylistic means used in the texts;

- to carry out a comparative analysis of the written discourse of Japanese literary studies in diachrony;

- to identify specific features of texts of Japanese literary studies.

\section{Methodology.}

Possible methods of study of professional texts of the Japanese literary terminology are as follows.

Statistical method (or linguo-statistical experiment, or quantitative analysis) is used to establish the quantitative and percentage composition of terminological units in professional texts of Japanese literary studies. Here are a detailed definition and algorithm of the statistical method. Linguo-statistical experiment is a method of quantitative linguistics aimed at obtaining quantitative characteristics of certain linguistic phenomena (frequency of phonemes, syllables, words, sentences, word length, sentence length, etc.) and establishing the reliability of statistical results. The first stage is to advance a certain hypothesis in 
accordance with the outlined aim and objectives. The second stage is to define (depending on the aim) the boundary of the general totality - the whole array of objects under study, united by certain qualitative and quantitative characteristics. The third stage is to process and statistically analyze the obtained results by separating variation series, compiling tables, diagrams, graphs, calculating the arithmetic mean. The fourth stage is to describe the laws established statistically, to interpret the obtained values, that is, a qualitative analysis of the phenomenon under study (Selivanova, 2006: 160, 307-308).

The second method use in this work is a functional analysis (to clarify the peculiarities of the use of terms in scientific texts) (Vakulenko, 2013: 18).

We have chosen the texts of poetic treatises written by the classics of Japanese literary studies as the source database for the study of Japanese literary terminology in the field of functioning. Such texts give new terms and form the semantics of a certain literary concept (Nikitina, 1987: 50). As a rule, literary treatises are written by professionals and addressed to professionals. Professional literary studies of Japan is presented in our source database by the texts of the following literary treatises:

Ki no Tsurayuki. "Kanajo. Kokin Wakashū". ("Preface. Collection of Japanese poems of ancient and modern times”, 905-913 紀貫之「古今和歌集」);

Ki no Yoshimochi. "Manajo. Kokin Wakashū". ("Preface. Collection of Japanese poems of ancient and modern times”, 905-913 紀義持「古今和歌集」);

Mibu no Tadamine. "Wakatei jisshu» (“Ten styles of Japanese poems”, $945 \mathrm{p}$. 壬生忠笒「和歌十種」);

Fujiwara no Kintō. "Waka kuhon». ("Nine degrees / skill / of Japanese poetry", 1011 th 藤原公任「和歌九品」);

Fujiwara no Teika. "Kindai shuka» («Beautiful poems of the new era", 1209, 藤原定家「近代秀歌」);

Fujiwara no Yoshitsune. "Kanajo. Shin Kokin Wakashū”. (“Preface. New Collection of Poems Ancient and Modern”, 1205 藤原良経「新古今和歌集仮名序」);

Go-Toba. "Manajo. Shin Kokin Wakashū". ("Preface. New collection of poems ancient and modern”, 1205 後鳥羽天皇「新古今和歌集序」);

Motoori Norinaga. "Jasper comb of "The Tale of Genji"”, 1796-1799 (本居宣長「源氏物語玉の小櫛」);

Ariga Nagao. “Literary theory”, 1885 (有賀長雄「文学論」);

Tsubouchi Shōyō. “Essence of prose”, 1885-1886 (坪内逍遥「小説神髄」);

Futabatei Shimei. “Novel review”, 1886 (二葉亭四迷「小説総論」);

Masaoka Shiki. “Chat about Bashō”, 1893 (正岡子規「芭蕉雑談」);

Taneda Santōka. “Ikusa-an diary”, 1940 (種田山頭火「一草庵日記」);

Naoya Shiga. “Rhythm”, 1959 (志賀直哉「リズム」);

Nakamura Murao. "True prose and prose about the inner world", 1925 (中村武羅夫「本格小説と心境小説と」)

Akutagawa Ryūnosuke "My view on the theory of "vatakushi-shosetsu"”, 1925 (芥川龍之介「私小説論写研」);

Itō Sei. “Literature history of modern Japan”, 1958 (伊藤整「近代日本の文学史」). 


\section{Results.}

\subsection{Definition of Basic Concepts and Terms Relevant to the Study of Textual Features of Japanese Literary Terminology.}

The starting point of this study, which will be the basis for the analysis of textual features of Japanese literary terminology, is the statement of terminologists about "the existence of terminology in two fields (within the language science, implemented in texts of various genres): in the field of fixation (lexicographic genres: special dictionaries, collections of recommended terms, terminological state standards) and in the field of functioning (special literature: articles, monographs, collective monographs, and partly popular science works)" (Danilenko, 1977: 15). According to terminologists, the terms in the fields of fixation and functioning have qualitative differences. "The meanings of terms in dictionaries and texts often do not correspond to each other, which is sometimes a manifestation of negligence in the use of terms, and sometimes it is an indicator of dissatisfaction with existing dictionary articles" (Nikitina, 1987: 50).

At the same time, scientists emphasize that "the term of any field of knowledge expresses a special professional concept (scientific, technical, socio-cultural) if it is used in terms of special professional communication: in written texts or oral speech of professionals" (Danilenko, 1977: 39). In addition to the actual special professional discourse, there is a known usage of terminological units in other genres of literature, which, as a rule, are not addressed to professionals. It is natural that the use of terminological units in the literature aimed at the audience of non-professionals has its own features, different from the discourse, where the addressee and the addresser are professionals. A brief overview of the specifics of the use of professional vocabulary in texts aimed at non-professionals will be presented below. As terminologists point out, in contrast to special literature, in a work of art the word realizes a non-terminological meaning, expressing a general idea or everyday concept (Danilenko, 1977: 38). The use of scientific terminology in popular science literature has its own specifics, which "seems to carry out a kind of "translation" of information from a special language, understandable only to those who are familiar with the system of concepts in this field of knowledge, into a language accessible to everyone" (Kvitko, 1987: 104). According to terminologists, in the popular science literature, information is inevitably lost when replacing more precise disciplinary terms, which have a smaller scope, with interdisciplinary and general scientific terms, the scope of which is wider but the content is less accurate, as well as with descriptions and non-terminological constructions as the task of such texts is to give only a general idea of the issue (Kvitko, 1987: 104-105). In the genre of educational literature, the use of scientific and technical terminology is characterized by strict normativity and has a number of features related to the age and educational level of readers (Kvitko, 1987: 93).

As we can see, terminologists unanimously state that the use of terms in educational publications, popular science works and works of art has its own specifics due to the purpose of these types of literature (Kvitko, 1987: 93). Summing up, we would like to note that the mentioned genres have the following features: 1) in fiction, the word implements the general idea or everyday concept; 2) in the popular science literature, the inevitable loss of information occurs when accurate disciplinary terms are replaced with inter-disciplinary and general scientific terms; 3 ) in the educational literature the number of use of terminological units is limited (Zhanghazinova, 2014 38; Kvitko, 1987: 93, 104-105).

Taking into account the peculiarities of the use of terminological units in the discourses "professional $\rightarrow$ non-professional" (popular science, educational literature) and "nonprofessional $\rightarrow$ non-professional" (works of art), which are expressed, as a rule, by the realization of the only partial or distorted (everyday) meaning of a certain term, we consider 
it necessary to pay the primary attention of our study to texts addressed to professionals, where the purity of the terminological meaning of a scientific concept is preserved. It should be noted that the texts addressed to non-professionals have a wide space for study and this is confirmed by numerous works of scientists: in the field of the use of terms in fiction (Ghrycaj, 2012; Khalinovsjka, 2003; Shatalina, 2009), in popular science texts and in educational literature (Asmukovych, 2014; Jacenko, 2007). However, given the limited scope of our study, let us focus on the analysis of professional texts of paramount (in our opinion) importance, leaving the study of the use of Japanese literary terminology in texts addressed to non-professionals for future studies.

Before proceeding directly to the solution of practical problems, it is necessary to dwell on the clarification of the semantics of terminological concepts, which will be used in the study of the functional features of the professional language of Japanese literary studies. The concept of supra-disciplinary, disciplinary and inter-disciplinary terminology remains controversial. The division of terms into general, inter-disciplinary and disciplinary is conditional and reflects the dialectical relationship of objects and phenomena of the material world (Kvitko, 1987: 23). Thus, there are different definitions of these concepts in the works of scientists.

V. M. Lejchik designates general scientific terms as general scientific concepts that have identical semantics in all fields of knowledge but specify these semantics, being part of the terminology of individual disciplines. According to V. M. Lejchik, inter-disciplinary terms are used in some fields of knowledge, specifying each time in their terminological systems: "Processing", "instrument", "class", "unit", "sign", "information". The so-called terms of broad semantics - lexical units (words) that are used in many terminological systems. However, if general scientific terms have the same semantics in any terminological system, which is only concretized, these lexical units have their own semantics, entering each of the terminological systems and retaining only a general, non-terminological meaning (for example, "staff composition", “chemical composition") (Lejchik, 2007: 127-128).

During the study of Japanese legal terminology, T. K. Komarnycjka uses the division of terminology into supra-disciplinary and disciplinary. Under the concept of supradisciplinary terminology, the researcher understands "a legal term available in two or more different sectoral terminological systems $\langle\ldots\rangle$ or in the texts of two or more regulations governing relations in different branches of law." The legal term "is considered to function in the legal discourse in general, i.e. supra-disciplinary" (Komarnycjka, 2010: 90), while the disciplinary terms, according to T. Komarnycjka, are only those terms that function in the special legal discourse of a particular branch of law (Komarnycjka, 2010: 90).

Investigating the aviation terminology, I. V. Asmukovych represents the functional features of the professional language of aviation in four groups of terms: general scientific, inter-disciplinary, disciplinary and highly specialized (Asmukovych, 2014: 9-10).

As the above examples show, there is a lack of consensus among scholars in defining: firstly, a single division of terms into general scientific, inter-disciplinary, disciplinary and others (each researcher forms their own system of division of terminology); secondly, the lack of approved definitions of inter-disciplinary, supra-disciplinary terms. As we can see, the researcher forms her own system of division of terminological units of a specific disciplinary terminology into general scientific, inter-disciplinary and disciplinary.

Taking into account the experience of previous researchers and taking into account the specifics of the terminology of Japanese literature, we consider it possible to propose a division of the terminology of Japanese literary studies into general, inter-disciplinary, supradisciplinary (general literary), disciplinary and terminology of other disciplines. We would like to note that we made the distribution of terminology of Japanese literature into these groups relying on the opinion of the makers of authoritative encyclopedic dictionaries of 
Japanese literary terms, in particular: Ichiko Teiji /市古貞次/ (日本古典文学大辞典 1985), Odagiri Susumu /小田切進 (日本近代文学大事典 1987), and Isoda Koichi /磯田光 $/$ (新朝日本文学辞典 1988). In these dictionaries, the authors provide a designation for a certain term as a component of a particular discipline of literary studies. Thus, in the case of indicating the authors of dictionaries on the affiliation of a terminological unit to only one discipline of literary studies, we classify such a unit as disciplinary. If the term is designated in two or more disciplines of literary studies, then we consider such unit as supradisciplinary. Accordingly, units designated as functioning in both literary studies and other kinds of arts, philosophy, or science (for example, music, Buddhism, fine arts) are referred to as inter-disciplinary.

Under the concept of general scientific terminology, following V. M. Lejchik, we understand "concepts that have identical semantics in all fields of knowledge but specify these semantics, being part of the terms of individual disciplines" (Lejchik, 2007: 127-128). Following I. S. Kvitko, we designate inter-disciplinary terms as concepts of broad scope, which reflect the commonality of the objects of study and are part of the terminology of related sciences (literary-philosophical, literary-aesthetic) (Kvitko, 1987: 22). Under the concept of terms of other disciplines, we understand the terminological units not related to literary terminology, which occur in the material of our study. We consider general literary terminology to be supra-disciplinary, i.e. one that is used in immutable semantics in all disciplines of literary studies. Disciplinary terminology refers to such terminological units that are used only in a particular discipline of literary studies.

This raises the question of dividing the Japanese literary terminology into the disciplines, according to which we will determine the boundaries of a particular element in literary studies. We consider it expedient to reconcile our division of the studied terminology into the disciplines with the classification by genres of literature accepted in literary studies. The phenomenon of the literary genre is explained as a way of expressing artistic content; according to the specification of V.Y. Halizev, it is a set of "principles of the formal organization of works, determined by the properties of both the subject of image and artistic speech" (Ghalych, 2001: 251; Halizev, 1986: 9). Most scholars agree that there are three genres of literature - epic, lyric and drama (Ghalych, 2001: 251). Works that combine features of epic, lyrical and dramatic genres are called lyric-epic, lyric-dramatic, etc. (Ghalych, 2001: 324). This classification is dominant in European literary studies. Japanese literary studies are subject to a similar classification by genres of literature. Thus, we consider it correct within our study to use the division of disciplines of Japanese literary studies into three main genres of literature - epics (日本古典散文 - nihon koten sanbun) lyrics (日本古典誌歌 - nihon koten shika) and drama (劇文学 - gekibungaku). We also consider it appropriate to involve several common in Japanese literature varieties of intermediate literary genres, namely - lyric-epic (詩歌散文 - shikasanbun), represented by genres utamonogstari, norito and lyric-dramatic (詩歌劇- shikageki), for example, genre naniwabushi. Following the Japanese scholars, who classify the folklore recorded in written sources as a kind of Japanese literature (民謡 min'yō) (Debejko, 2006: 37), we propose during our study to consider folklore works along with epic, lyric, drama and lyric-epic as a separate discipline of Japanese literature.

Thus, having clarified the definition of concepts that will be used in the study of functional features of Japanese literary terminology, let us highlight the main stages of practical work on the textual features of the analysed terminology. Firstly, we will establish the percentage of terminological saturation of professional texts of Japanese literary studies with the help of quantitative analysis. Secondly, we will determine the proportional ratio of general scientific, inter-disciplinary, supra-disciplinary (general literary) and disciplinary terminological units and 
terms of other disciplines within the studied terminology. Thirdly, we will analyse the stylistic features of the texts of Japanese literary treatises. Fourthly, as part of the studied disciplinary terminology, we will set the percentage of units within the fundamental disciplines of Japanese literary studies: epic, lyric, drama, lyric-epic, lyric-drama and folklore.

\subsection{Percentage of literary and general literary vocabulary.}

Naturally, the professional texts of each individual disciplinary terminology have an individual proportion of terminological and general literary vocabulary due to the practical needs of the professional language. Thus, based on the English language materials, scientists have established the following indicators of terminological saturation of professional texts in the following disciplines: astronomy $-55 \%$, economics $-35 \%$, linguistics $-30 \%$, mechanical engineering - 60\% (Shevchenko, 2010: 15], aviation - 56\% (Asmukovych, 2014: 14]. The percentage of professional vocabulary established by us in Japanese literary treatises is given below in the table.

Table 1

Correlation of Terminological and General Literary Vocabulary in Professional Texts of Japanese Literary Studies

\begin{tabular}{|c|c|c|c|c|}
\hline No. & Text & $\begin{array}{l}\text { Number of } \\
\text { meaningful } \\
\text { word usage }\end{array}$ & $\begin{array}{c}\text { General } \\
\text { vocabulary }\end{array}$ & Literary terminology \\
\hline 1 & $\begin{array}{l}\text { Ki no Tsurayuki. "Preface } \\
\text { (Kanajo). Kokin Wakashü" } \\
\text { ("Collection of Japanese } \\
\text { poems of ancient and modern } \\
\text { times"), 905-913. }\end{array}$ & 1696 & $\begin{array}{c}1509 \\
(89 \%)\end{array}$ & $\begin{array}{c}187 \\
(11 \%)\end{array}$ \\
\hline 2 & $\begin{array}{l}\text { Ki no Yoshimochi. "Preface } \\
\text { (Manajo). Kokin Wakashū" } \\
\text { ("Collection of Japanese } \\
\text { poems of ancient and modern } \\
\text { times"), 905-913. }\end{array}$ & 952 & $\begin{array}{c}790 \\
(83 \%)\end{array}$ & $\begin{array}{c}162 \\
(17 \%)\end{array}$ \\
\hline 3 & $\begin{array}{l}\text { Mibu no Tadamine "Ten } \\
\text { styles of Japanese poems", } \\
(945)\end{array}$ & 544 & $\begin{array}{c}359 \\
(66 \%)\end{array}$ & $\begin{array}{c}185 \\
(34 \%)\end{array}$ \\
\hline 4 & $\begin{array}{l}\text { Fujiwara no Kintō "Nine } \\
\text { degrees / skill / of Japanese } \\
\text { poetry", (10-11 th). }\end{array}$ & 216 & $\begin{array}{c}110 \\
(51 \%)\end{array}$ & $\begin{array}{c}106 \\
(49 \%)\end{array}$ \\
\hline 5 & $\begin{array}{l}\text { Fujiwara no Teika. "Kindai } \\
\text { shuka" ("Beautiful poems of } \\
\text { the new era"), } 1209 \text {. }\end{array}$ & 728 & $\begin{array}{c}568 \\
(78 \%)\end{array}$ & $\begin{array}{c}160 \\
(22 \%)\end{array}$ \\
\hline 6 & $\begin{array}{l}\text { Fujiwara no Yoshitsune. } \\
\text { "Kanajo. Shin Kokin } \\
\text { Wakashū". ("Preface. New } \\
\text { Collection of Poems Ancient } \\
\text { and Modern"), 1205. }\end{array}$ & 1096 & $\begin{array}{c}997 \\
(91 \%)\end{array}$ & $\begin{array}{c}99 \\
(9 \%)\end{array}$ \\
\hline 7 & $\begin{array}{l}\text { Go-Toba. "Manajo. Shin } \\
\text { Kokin Wakashū". ("Preface. } \\
\text { New collection of poems } \\
\text { ancient and modern"), } 1205 \text {. }\end{array}$ & 888 & $\begin{array}{c}781 \\
(88 \%)\end{array}$ & $\begin{array}{c}107 \\
(12 \%)\end{array}$ \\
\hline 8 & $\begin{array}{l}\text { Motoori Norinaga. "Jasper } \\
\text { comb of "The Tale of } \\
\text { Genji",", (1796-1799) }\end{array}$ & 1056 & $\begin{array}{c}993 \\
(94 \%)\end{array}$ & $\begin{array}{c}63 \\
(6 \%)\end{array}$ \\
\hline 9 & $\begin{array}{lll}\text { Ariga } & \text { Nagao. } & \text { "Literary }\end{array}$ & 1592 & 1433 & 159 \\
\hline
\end{tabular}




\begin{tabular}{|c|c|c|c|c|}
\hline No. & Text & $\begin{array}{l}\text { Number of } \\
\text { meaningful } \\
\text { word usage }\end{array}$ & $\begin{array}{c}\text { General } \\
\text { vocabulary }\end{array}$ & Literary terminology \\
\hline & theory", (1885) & & $(90 \%)$ & $(10 \%)$ \\
\hline 10 & $\begin{array}{l}\text { Tsubouchi Shōyō. "Essence } \\
\text { of prose", (1885-1886) }\end{array}$ & 1776 & $\begin{array}{l}1368 \\
(77 \%)\end{array}$ & $\begin{array}{c}408 \\
(23 \%)\end{array}$ \\
\hline 11 & $\begin{array}{l}\text { Futabatei Shimei. "Novel } \\
\text { review", (1886) }\end{array}$ & 1128 & $\begin{array}{c}914 \\
(81 \%) \\
\end{array}$ & $\begin{array}{c}214 \\
(19 \%) \\
\end{array}$ \\
\hline 12 & $\begin{array}{l}\text { Masaoka Shiki. "Chat about } \\
\text { Bashō", (1893) }\end{array}$ & 440 & $\begin{array}{c}378 \\
(86 \%)\end{array}$ & $\begin{array}{c}62 \\
(14 \%)\end{array}$ \\
\hline 13 & $\begin{array}{l}\text { Taneda Santōka. "Ikusa-an } \\
\text { diary", (1940) }\end{array}$ & 280 & $\begin{array}{c}241 \\
(85 \%)\end{array}$ & $\begin{array}{c}41 \\
(15 \%)\end{array}$ \\
\hline 14 & $\begin{array}{lll}\text { Naoya } & \text { Shiga. "Rhythm", } \\
(1959)\end{array}$ & 952 & $\begin{array}{c}762 \\
(80 \%)\end{array}$ & $\begin{array}{c}190 \\
(20 \%)\end{array}$ \\
\hline 15 & $\begin{array}{l}\text { Nakamura Murao. "True } \\
\text { prose and prose about the } \\
\text { inner world", (1925) }\end{array}$ & 1624 & $\begin{array}{c}1364 \\
(84 \%)\end{array}$ & $\begin{array}{c}260 \\
(16 \%)\end{array}$ \\
\hline 16 & $\begin{array}{l}\text { Akutagawa Ryūnosuke "My } \\
\text { view on the theory of } \\
\text { "vatakushi-shosetsu"”, (1925) }\end{array}$ & 1408 & $\begin{array}{c}697 \\
(49.5 \%)\end{array}$ & $\begin{array}{c}711 \\
(50.5 \%)\end{array}$ \\
\hline 17 & $\begin{array}{l}\text { Itō Sei. "Literature history of } \\
\text { modern Japan", (1958) }\end{array}$ & 1352 & $\begin{array}{c}1142 \\
(84.5 \%)\end{array}$ & $\begin{array}{c}210 \\
(15.5 \%)\end{array}$ \\
\hline
\end{tabular}

Ratio of the use of literary terminology to the total amount of vocabulary in the text does not have a clear gradation in time but rather is a manifestation of the individual style of the author of the treatise. Thus, the highest terminological saturation is represented by in works of Akutagawa Ryūnosuke (10th) - 50.5\% and Fujiwara no Kintō (10-11th) - 49\%. The average rate of terminological saturation of treatises of the ancient and medieval periods of Japanese literary studies is $22 \%$, and of the modern period (from the beginning of the Meiji era) is $20.15 \%$. We suggest that the reason for almost identical indicators of the proportional ratio of general literary and terminological vocabulary in professional texts of the tenth and twentieth centuries lies in the established tradition of composing literary works, which is reflected in the number of terminological units. Obviously, the observance of such a tradition is both conscious when the author clearly imitates the structure, stylistic nuance of an authoritative literary critic (for example, the preface (manajo) of Ki no Tsurayuki to the poetic anthology "Kokin Wakashū" became a model for imitation for Mibu no Tadamine, Ki no Yoshimochi and other authors), and the subconscious imitation by avant-garde poets of their predecessors, who wrote about the need to "throw out the achievements of the classics of the ship of modernity." However, in our opinion, during the century of isolation of the country and adherence to exclusively traditional methods in the art, writers could not subconsciously deviate from the canonical rules of writing literary treatises or at least the part concerning the terminological and stylistic saturation of the work. Thus, the highest terminological saturation is represented in works of Akutagawa Ryūnosuke (10th) $-50.5 \%$ and Fujiwara no Kintō (10-11th) - 49\%.

The average terminological saturation of professional texts in Japanese literary studies is $20.11 \%$. This indicator is considered low compared to the indicators of other disciplines. Obviously, this is a consequence of the following stylistic features: the frequent use of detailed comparisons of certain literary concepts with the concepts of other disciplines of art, nature, history etc. Example:

それ、まくらことば、春の花包ひ、少なくして、空しき名のみ、秋の夜の、長きを託てれば。Our work lacks the aroma of spring flowers, but the glory is vanity, even if it is as long as an autumn night. (Ki no Tsurayuki). 
It is obvious that comparison as a stylistic means is used by creators of poetic treatises similar to authors of traditional Japanese poetry in order to attract a wide range of traditional symbolic words, which are sure to evoke a number of associations with the educated reader. Masaoka Shiki wrote: "With these associations, for the first time, a universe of seventeen compositions generates boundless artistic taste. Therefore, people who cannot recognize seasonal associations in haiku are unable to fully understand the poem" (Masaoka Shiki 2013: 177).

The treatises of the authors of the XX - XXI centuries often have comparisons of literary phenomena or processes with the concepts of other sciences. Naturally, the appeal to the description of the concepts of other fields of knowledge involves the attraction of a certain number of terminological units that are not included in literary studies. The conscious use by the authors of the treatises of a certain array of terms of other fields of knowledge, both related (culture, art) and remote (medicine, politics) provided for the addressee's comprehensive erudition.

The presence of comparisons of literary concepts with other concepts of the surrounding world and, accordingly, the integration into the text of a literary treatise of extended detailed descriptions of concepts and terms from other disciplines, in our opinion, has an extralinguistic reason: the world-view of the Japanese is inseparable from nature and the surrounding world and presupposes a harmonious combination of several disciplines, as well as a vision of the qualities of one in another (for example, to see the Universe in a dewdrop, etc.). Along with the use of comparisons, we observe another stylistic feature of professional texts in Japanese literary studies: binding the text of a literary treatise to the historical background. Thus, the authors of the medieval period, before proceeding the direct presentation of literary thoughts, devote some part of the text to the description of the historical context: the reign of a certain emperor (contemporary to the author or from a past period). The authors of the XX century layout literary theoretical developments in the context of reflections on the development of scientific and technological progress. We also observe an appeal to the creative heritage of authoritative predecessors, which, of course, is a consequence of the cult of the teacher (sensei / 先生/) in Eastern culture. Often, along with recognized artists, the authors of treatises mention the works of several of their colleagues, which, in our opinion, is a manifestation of collectivism.

\subsection{General Scientific, Supra-Disciplinary (General Literary) and Highly} Specialized (Disciplinary) Literary Terminology in Japanese: Correlation and Features.

Thus, using quantitative analysis, let us determine the quantitative and percentage composition of these groups of terms in the texts of Japanese literary treatises.

Table 2

Correlation of General Scientific, Inter-Disciplinary,

Supra-Disciplinary, Disciplinary Terminology and Professional Vocabulary of Other Sciences in Professional Texts of Japanese Literary Studies

\begin{tabular}{|c|c|c|c|c|c|c|}
\hline No. & Text & 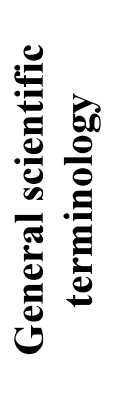 & 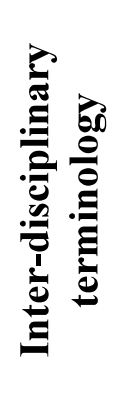 & 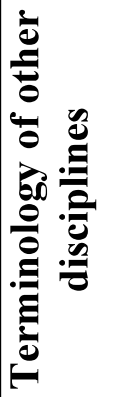 & 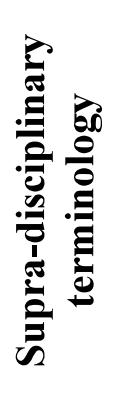 & 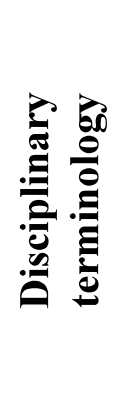 \\
\hline 1 & 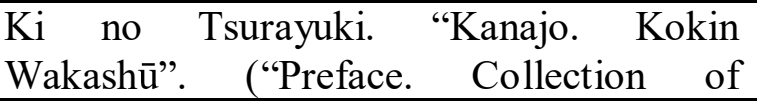 & $\begin{array}{c}6 \\
3 \%\end{array}$ & $\begin{array}{c}3 \\
1.5 \%\end{array}$ & $\begin{array}{c}3 \\
1.5 \%\end{array}$ & $\begin{array}{c}0 \\
0 \%\end{array}$ & $\begin{array}{c}129 \\
94 \%\end{array}$ \\
\hline
\end{tabular}




\begin{tabular}{|c|c|c|c|c|c|c|}
\hline No. & Text & 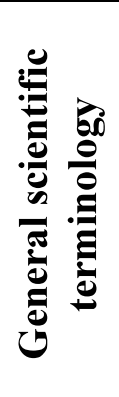 & 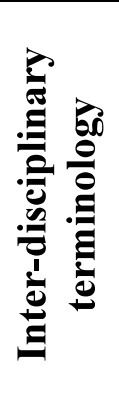 & 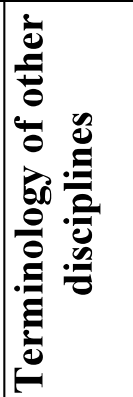 & 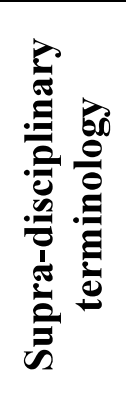 & 绨 \\
\hline & $\begin{array}{l}\text { Japanese poems of ancient and modern } \\
\text { times", 905-913 紀貫之「古今和歌集」); }\end{array}$ & & & & & \\
\hline 2 & $\begin{array}{l}\text { Ki no Yoshimochi. "Manajo. Kokin } \\
\text { Wakashū". ("Preface. Collection of } \\
\text { Japanese poems of ancient and modern } \\
\text { times", 905-913 紀義持「古今和歌集」); }\end{array}$ & $\begin{array}{c}6 \\
3 \%\end{array}$ & $\begin{array}{c}6 \\
3 \%\end{array}$ & $\begin{array}{c}0 \\
0 \%\end{array}$ & $\begin{array}{c}7 \\
4 \%\end{array}$ & $\begin{array}{c}143 \\
88 \%\end{array}$ \\
\hline 3 & $\begin{array}{l}\text { Mibu no Tadamine. "Wakatei jisshu» (“Ten } \\
\text { styles of Japanese poems", } 945 \text { p. } \\
\text { 壬生忠岑「和歌十種」); }\end{array}$ & $\begin{array}{c}13 \\
7 \%\end{array}$ & $\begin{array}{c}4 \\
2 \%\end{array}$ & $\begin{array}{c}0 \\
0 \%\end{array}$ & $\begin{array}{c}0 \\
0 \%\end{array}$ & $\begin{array}{c}168 \\
91 \%\end{array}$ \\
\hline 4 & $\begin{array}{l}\text { Fujiwara no Kintō. "Waka kuhon». ("Nine } \\
\text { degrees / skill / of Japanese poetry", 10- } \\
11 \text { th 藤原公任「和歌九品」); }\end{array}$ & $\begin{array}{c}54 \\
50 \%\end{array}$ & $\begin{array}{c}3 \\
2 \%\end{array}$ & $\begin{array}{c}0 \\
0 \%\end{array}$ & $\begin{array}{c}1 \\
1 \%\end{array}$ & $\begin{array}{c}50 \\
47 \%\end{array}$ \\
\hline 5 & $\begin{array}{l}\text { Fujiwara no Teika. “Kindai shuka» } \\
\text { («Beautiful poems of the new era”, 1209, } \\
\text { 藤原定家「近代秀歌」); }\end{array}$ & $\begin{array}{c}0 \\
0 \%\end{array}$ & $\begin{array}{c}14 \\
9 \%\end{array}$ & $\begin{array}{c}0 \\
0 \%\end{array}$ & $\begin{array}{c}0 \\
0 \%\end{array}$ & $\begin{array}{c}146 \\
91 \%\end{array}$ \\
\hline 6 & $\begin{array}{l}\text { Fujiwara no Yoshitsune. "Kanajo. } \\
\text { Kokin Shin } \\
\text { Collection of Poems Ancient and Modern", } \\
1205 \\
\text { 藤原良経「新古今和歌集仮名序」); }\end{array}$ & $\begin{array}{c}0 \\
0 \%\end{array}$ & $\begin{array}{c}0 \\
0 \%\end{array}$ & $\begin{array}{c}0 \\
0 \%\end{array}$ & $\begin{array}{c}0 \\
0 \%\end{array}$ & $\begin{array}{c}99 \\
100 \%\end{array}$ \\
\hline 7 & $\begin{array}{l}\text { Go-Toba. "Manajo. Shin Kokin Wakashū". } \\
\text { ("Preface. New collection of poems ancient } \\
\text { and } \quad 1205 \\
\text { modern”, }\end{array}$ & $\begin{array}{c}0 \\
0 \%\end{array}$ & $\begin{array}{c}0 \\
0 \%\end{array}$ & $\begin{array}{c}3 \\
3 \%\end{array}$ & $\begin{array}{c}0 \\
0 \%\end{array}$ & $\begin{array}{c}104 \\
97 \%\end{array}$ \\
\hline 8 & $\begin{array}{l}\text { Motoori Norinaga. “Jasper comb of “The } \\
\text { Tale of Genji”", 1796-1799 } \\
\text { (本居宣長「源氏物語玉の小櫛」); }\end{array}$ & $\begin{array}{c}8 \\
12 \%\end{array}$ & $\begin{array}{c}2 \\
3 \%\end{array}$ & $\begin{array}{c}21 \\
34 \%\end{array}$ & $\begin{array}{c}4 \\
7 \%\end{array}$ & $\begin{array}{c}28 \\
44 \%\end{array}$ \\
\hline 9 & $\begin{array}{l}\text { Ariga Nagao. “Literary theory”, } 1885 \\
\text { (有賀長雄「文学論」); }\end{array}$ & $\begin{array}{c}81 \\
51 \% \\
\end{array}$ & $\begin{array}{c}6 \\
4 \% \\
\end{array}$ & $\begin{array}{c}72 \\
45 \% \\
\end{array}$ & $\begin{array}{c}0 \\
0 \% \\
\end{array}$ & $\begin{array}{c}0 \\
0 \% \\
\end{array}$ \\
\hline 10 & $\begin{array}{l}\text { Tsubouchi Shōyō. "Essence of prose", } \\
\text { 1885-1886 (坪内逍遥「小説神髄」); }\end{array}$ & $\begin{array}{c}61 \\
15 \%\end{array}$ & $\begin{array}{c}33 \\
8 \%\end{array}$ & $\begin{array}{c}0 \\
0 \%\end{array}$ & $\begin{array}{c}155 \\
38 \%\end{array}$ & $\begin{array}{c}122 \\
30 \%\end{array}$ \\
\hline 11 & $\begin{array}{l}\text { Futabatei Shimei. “Novel review”, } 1886 \\
\text { (二葉亭四迷「小説総論」); }\end{array}$ & $\begin{array}{c}58 \\
73 \%\end{array}$ & $\begin{array}{c}13 \\
6 \%\end{array}$ & $\begin{array}{c}4 \\
2 \%\end{array}$ & $\begin{array}{c}21 \\
10 \%\end{array}$ & $\begin{array}{c}19 \\
9 \%\end{array}$ \\
\hline 12 & $\begin{array}{l}\text { Masaoka Shiki. “Chat about Bashō”, } 1893 \\
\text { (正岡子規「芭蕉杂倠談」); }\end{array}$ & $\begin{array}{c}10 \\
16 \%\end{array}$ & $\begin{array}{c}8 \\
13 \%\end{array}$ & $\begin{array}{c}17 \\
27 \%\end{array}$ & $\begin{array}{c}7 \\
11 \% \\
\end{array}$ & $\begin{array}{c}20 \\
32 \%\end{array}$ \\
\hline 13 & $\begin{array}{l}\text { Taneda Santōka. “Ikusa-an diary”, } 1940 \\
\text { (種田山頭火「一草庵日記」); }\end{array}$ & $\begin{array}{c}5 \\
12 \%\end{array}$ & $\begin{array}{c}12 \\
29 \%\end{array}$ & $\begin{array}{c}7 \\
17 \%\end{array}$ & $\begin{array}{c}1 \\
2 \%\end{array}$ & $\begin{array}{c}18 \\
39 \%\end{array}$ \\
\hline 14 & $\begin{array}{l}\text { Naoya Shiga. } \\
\text { (志賀直哉「リズム」); }\end{array}$ & $\begin{array}{c}11 \\
6 \%\end{array}$ & $\begin{array}{c}36 \\
19 \%\end{array}$ & $\begin{array}{c}8 \\
4 \%\end{array}$ & $\begin{array}{c}108 \\
57 \%\end{array}$ & $\begin{array}{c}5 \\
2.5 \%\end{array}$ \\
\hline 15 & $\begin{array}{l}\text { Nakamura Murao. "True prose and prose } \\
\text { about the inner world", } 1925\end{array}$ & $\begin{array}{c}60 \\
23 \% \\
\end{array}$ & $\begin{array}{c}10 \\
4 \% \\
\end{array}$ & $\begin{array}{c}0 \\
0 \% \\
\end{array}$ & $\begin{array}{c}146 \\
56 \%\end{array}$ & $\begin{array}{c}44 \\
17 \% \\
\end{array}$ \\
\hline
\end{tabular}




\begin{tabular}{|c|c|c|c|c|c|c|}
\hline No. & Text & 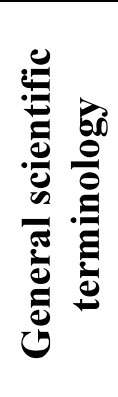 & 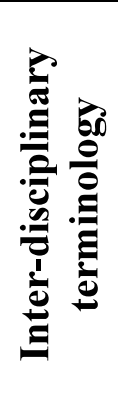 & 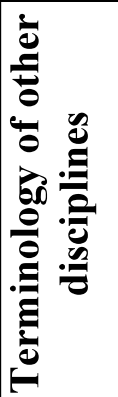 & 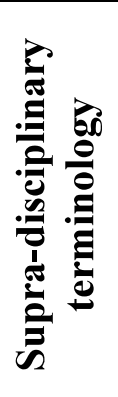 & 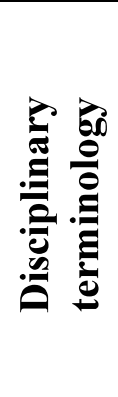 \\
\hline & (中村武羅夫「本格小説と心境小説と」) & & & & & \\
\hline 16 & $\begin{array}{l}\text { Akutagawa Ryūnosuke “My view on the } \\
\text { theory of “vatakushi-shosetsu"”, } 1925 \\
\text { (芥川龍之介「私小説論写研」); }\end{array}$ & $\begin{array}{c}135 \\
19 \%\end{array}$ & $\begin{array}{c}28 \\
4 \%\end{array}$ & $\begin{array}{c}0 \\
0 \%\end{array}$ & $\begin{array}{c}29 \\
4 \%\end{array}$ & $\begin{array}{c}519 \\
72 \%\end{array}$ \\
\hline 17 & $\begin{array}{l}\text { Itō Sei. “Literature history of modern } \\
\text { Japan”, } \\
\text { (伊藤整「近代日本の文学史」). }\end{array}$ & $\begin{array}{c}17 \\
9 \%\end{array}$ & $\begin{array}{c}46 \\
23 \%\end{array}$ & $\begin{array}{c}0 \\
0 \%\end{array}$ & $\begin{array}{c}109 \\
53 \%\end{array}$ & $\begin{array}{c}29 \\
15 \%\end{array}$ \\
\hline
\end{tabular}

The average indicator of terminological saturation of texts with individual analysed groups of terms, according to the results of our study, is as follows:

- general scientific terminology $-18 \%$;

- inter-disciplinary terminology $-8 \%$;

- terminology of other disciplines $-8 \%$;

- supra-disciplinary terminology $-15 \%$;

- disciplinary terminology $-51 \%$.

As we can see, the highest average indicator refers to the disciplinary terminology, which confirms the axiomatic statement of terminologists that disciplinary terms due to the narrow scope of correlated concepts have a clear, precise meaning, and therefore are understandable only to professionals (Kvitko, 1987: 23), and therefore are mostly presented in texts addressed to professionals.

Some of the treatises we have studied have a lower indicator of disciplinary terminology than supra-disciplinary and general science terminology. It is obvious that the dominance of general scientific and supra-disciplinary terminology in such texts confirms the above opinion on the specific features of professional texts of Japanese literary studies, which lie in observing the tradition of composing the treatise, which, in its turn, requires the involvement of the historical and cultural context incorporated into the text of literary work with the help of general scientific, cross-disciplinary and terms of other disciplines.

The following are examples of terminological units of Japanese literary studies, declared in this article as general scientific, inter-disciplinary, terms of other disciplines, supra-disciplinary and disciplinary.

General scientific terminology is presented in the studied works of Japanese literary studies mainly by the following terms: hatsuansha no kangae (発案者の考え, “author's opinion” - Nakamura Murao), hatsuansha no sekaikan (発案者の世界観 “author's worldview” - Nakamura Murao), shurui (種類 “type” - Akutagawa Ryūnosuke), hatsumeika (発朋家 “inventor” - Naoya Shiga), hatsumei (発明 “invention” - Naoya Shiga), bumon ni wakare (部門こわかれ, “classify”-Tsubouchi Shōyō), kakkantekina (客観的な, “objective” - Nakamura Murao), mondai (問題 “problem” - Naoya Shiga), henshu (変種 “variety" - Tsubouchi Shōyō), kaika (開花 “blooming” - Tsubouchi Shōyō), seido (制度 “system” - Naoya Shiga), tokushusei (特殊生, “peculiarity” - Naoya Shiga), shukanteki (主観的 “subjective” Nakamura Murao), bumen (部面 “branch” - Nakamura Murao), sōzō (凔造 “creativity” Naoya Shiga); te:zu (テーズ, "thesis” - Naoya Shiga), riron (理侖 “theory” - Naoya Shiga), 
taipu (タイプ, “type” - Akutagawa Ryūnosuke), genshō (現象 “phenomenon” - Nakamura Murao) etc.

Inter-disciplinary terminological units in the professional texts of Japanese literary studies are represented mainly by the following units: jūhan (重版, "reissue" - Tsubouchi Shōyō) book publishing - literary studies, kikan (期間 "period" - Itō Sei) history - literature, rizumu (リズム, “rhythm” - Taneda Santōka) music - poetry, shōchō (象徵 “symbol” Taneda Santōka) philosophy - art - literature, bun (文 "text" - Itō Sei) linguistics literature, geijutsusei (芸術性 “artistry” - Akutagawa Ryūnosuke) art - literature etc. As we can see, the inter-disciplinary terminological units are mainly represented in our source database by terminological units of such sciences related to literary studies as art, linguistics, history and philosophy.

The concepts of other sciences in the studied terminology are also represented by a group of terminological units, which were organically woven into the texts of literary treatises mainly for the purpose of comparison, allegory, stylistic ornaments. Here are some examples of the following units: shimpōsha (信奉者, “adept" -Masaoka Shiki) /religion/, saikoōdaka (採鎕高, “ore mining” - Ariga Nagao) /metallurgy/, jōkikikan hatsumei (蒸気機関発明, “invention of steam engine” - Ariga Nagao) /physics, mechanical engineering/, suimo (水素 “hydrogen” - Ariga Nagao) /chemistry/, oto-nohamo:ni: (音のハーモニー, "harmony of sounds" -Ariga Nagao) /music/, denkikigu(電気器具 "electrical appliances" Ariga Nagao) /physics/, jōcho (情者 “emotions” - Ariga Nagao) /psychology/, sanso (酸素 “oxygen” - Ariga Nagao) /chemistry/, chūgōku-no hōritsu(中国の法律, “Chinese laws” Ariga Nagao) /jurisprudence/, uchūno genshō (宇宙の現象 “cosmic phenomena” - Ariga Nagao) /astronomy/, hitetsu to ganseki (非鉄岩石 “metals and stones" - Ariga Nagao) /geology/, nehan (涅槃 “nirvana” - Taneda Santōka) /religion/, kisohōritsu gaku (基礎去律学, “fundamentals of jurisprudence”-Ariga Nagao) /jurisprudence/, nigirizumutō (二ギリズム党 "Nigilist Party" Ariga Nagao)/history, politics/, shihonshūseki (資本集皘 “share of capital”Ariga Nagao) /economy/, puroretaria katsudoka (プロレタリア活動家, “proletarian figure” Naoya Shiga)/history, politics/, jiyunokyōsō (自由の競争, “freedom of competition” - Ariga Nagao) /economy/, kotoba (言葉 “word” - Motoori Norinaga) /linguistics/, netsudo (熱度, “temperature” - Ariga Nagao) /physics/, chōetsuteki (超越的 “transcendent” - Naoya Shiga) /philosophy/ etc. These terminological units are taken from a wide range of sciences (physics, chemistry, economics, jurisprudence, astronomy, etc.) that are quite distant from literary studies. Naturally, the terms of other sciences, presented in the texts of literary treatises, are not highly specialized but well-known concepts.

The following are examples of supra-disciplinary terminological units of Japanese literary studies, i.e. those that function equally in all disciplines of literary studies (poetry, drama, epic, etc.): sakusha (作者, “author" - Fujiwara no Kintō, Tsubouchi Shōyō, Motoori Norinaga), bungakusho (文学書, "literary work”-Masaoka Shiki, Naoya Shiga, Tsubouchi Shōyō), wabun (和文 “Japanese literature” - Itō Sei), kanun (漢文 “medieval way of writing based on the Chinese literary language wen-yan" - Ki no Yoshimochi), purotto (プロット, "plot" - Naoya Shiga), bungei sakuhin (文芸作品 "literary work" - Masaoka Shiki, Tsubouchi Shōyō, Motoori Norinaga), dokusha(読者, “reader” - Tsubouchi Shōyō) etc. As is well known, supra-disciplinary terms constitute the backbone of any terminology, on which the terms with narrower semantics (disciplinary or highly-disciplinary) are strung.

Disciplinary terms, i.e. those that operate exclusively in one specific discipline of literary studies, are presented in our source database by the following examples:

- gesaku (虥作, verb.: “entertaining”, “humorous”) - entertaining literature (Tsubouchi Shōyō) /epic 散文; 
- monogatari (物語 verb.: “story"; from “mono-o kataru” - "to tell about something”) - a narrative Japanese prose of the Heian period (Tsubouchi Shōyō) /epic 散文;

- rokkasen(六歌仙 verb.: “six immortals") - six outstanding poets of the Heian period (Ki no Tsurayuki) /lyrics 詩歌;

- soe uta(そへ/え/歌) - a hint song, allegorical poem (Ki no Tsurayuki) /lyrics 詩歌;

- tadagotouta (唯 (徒只) 事歌 verb.: “Song about ordinary things") - a poem whose content is disclosed without involving any artistic media, tropes or images and symbols, but only with the help of words used in the literal sense (Ki no Tsurayuki) /lyrics 詩歌;

- haijin(俳人) - a Haikai poet (Taneda Santōka.) /lyrics 詩歌/;

- haikai (俳句, verb.: “comic lines") - a genre of Japanese poetry with a strophic form of 5-7-5 (Taneda Santōka.) /lyrics 詩歌;

- shosetsu (小説) - narrative prose (Tsubouchi Shōyō);

- shofu (蕉風 verb.: "Bashō style") - a Bashō (Shōmon) school style (Masaoka Shiki) /lyrics 詩歌.

\subsection{Correlation of Disciplinary Terms in Japanese Literary Studies.}

Let us find out the quantitative ratio of terminological units in separate disciplines of Japanese literary studies. For the objectivity of the result, it is necessary to involve materials from literary dictionaries, which, in contrast to professional texts that are characterized by a predetermined topic of a particular discipline, have a neutral disciplinary connotation. Next, with the help of quantitative analysis, we will establish the percentage of terminological units of each of the above-classified disciplines of literary studies. Thus, having analysed 20 random pages of dictionaries (日本古典文学大辞典 1985; 新朝日本文学辞典 1988; 日本文学辞典 1954), we have obtained the following average results of disciplinary affiliation of terminological units: Lyrics - 69 units (or $62 \%$ ), epic - 16 units (or $14 \%$ ), drama - 15 units (or 13,5\%), lyric-epic - 2 units (or 1,5\%), lyric-drama - 6 units (or $5 \%$ ) and folklore -4 units (or $4 \%$ ).

The significant predominance of the share of terminological units in the discipline of lyrics is quite natural for Japanese literature and is due to the peculiarities of the history of Japanese literature, where, as we know, for centuries (since the VIII century) the lyrics was considered high art, while other disciplines were not valued: the prose was considered to be a frivolous entertainment of court ladies, and the folklore as a work of the common people did not often get into imperial anthologies (and, therefore, remained without the attention of literary scholars).

It is logical that for a long time the terms were mostly enunciated from the discipline of poetics, which in particular was contributed by the poetic schools, the existence of the Ministry of Poetry at the Imperial Court from the tenth century, etc. Thus, as we can see, the quantitative predominance of terminological units in the discipline of lyrics is mainly due to support for the development of poetry, in particular at the state level, while epic, folklore, some genres of drama developed in the underground and therefore, terminological units that serve these disciplines, were enunciated in smaller quantities, or were lost in the depths of ages because they were not recorded in written sources.

\section{Discussion.}

The indicator of terminological saturation of texts with individual analyzed groups of terms, according to the results of our study, is as follows:

- general scientific terminology $-18 \%$;

- inter-disciplinary terminology $-8 \%$;

- terminology of other disciplines $-8 \%$; 
- supra-disciplinary terminology - $15 \%$;

- disciplinary terminology $-51 \%$.

The terms of other sciences, which were included in the texts of literary treatises, are not highly specialised but well-known concepts that were organically woven into the texts of literary treatises, mainly for comparison and stylistic ornaments.

For the objectivity of the result, the quantitative ratio of terminological units in certain disciplines of Japanese literary studies was calculated based on literary dictionaries, which, unlike professional texts (which have a predetermined subject of a particular discipline), have a neutral disciplinary connotation. According to the results of quantitative analysis, we have the following ratio of terminology in the disciplines of Japanese literary studies: lyrics $62 \%$, epic $-14 \%$, drama $-13.5 \%$, lyric-epic $-1.5 \%$, lyric-drama $-5 \%$, folklore $-4 \%$. The reason for the significant quantitative predominance of terminological units in the discipline of lyrics is seen in the history of Japanese literature, where, as we know, for centuries (since the VIII century) the lyric was considered high art.

\section{Conclusions.}

According to the results of the quantitative analysis, the average terminological saturation of professional texts in Japanese literary studies is $20 \%$. In our opinion, the low aggregate indicator of terminological saturation of Japanese literary texts is due to stylistic features, namely, the frequent use of extended comparisons, which occupy a significant part of the treatise text and involve concepts from other disciplines of art. Following the example of traditional Japanese poetry authors, it is obvious that the comparisons in literary treatises are used in order to attract a wide range of traditional symbolic words, which are sure to evoke a number of associations with the educated reader. In our opinion, the low percentage of terminological saturation of Japanese literary treatises is also due to the depiction by the authors of the studied texts of modern or past historical background. Obviously, this style of writing is an imitation of the traditional epistolary style of the Japanese language, which involves the presentation of the theme of the work in the context of phenomena that have a rather indirect relationship to the main theme.

\section{References}

Abakumova, S. S., \& Lukina S. L. (2011) Funkcionirovanie jekonomicheskih terminov v pis'mennom i ustnom diskurse [Functioning of economic terms in written and oral discourse]. Vestnik VGU. Serija: lingvistika i mezhkul'turnaja kommunikacija, 1, 166-170.

Adylova, Z. T. (2017). Systema shakhovykh nomeniv terminologhichnogho polja «debjut» [System Chess Nomina of Terminological Field "Debut"]. Naukovyj chasopys Nacionaljnogho pedaghoghichnogho universytetu imeni M. P Draghomanova: Serija 9 Suchasni tendenciji rozvytku mov, 16, 5-11.

Anistratenko, L. S. (2015). Afiksaljnyj sposib terminotvorennja $v$ japonsjkij literaturoznachij terminologhiji [Affixal method of term formation in Japanese literary terminology]. Movni i konceptualjni kartyny svitu, 54, 8-13.

Anistratenko, L. S. (2016). Zapozychennja jak sposib terminotvorennja japonsjkoji literaturoznavchoji terminologhiji [Borrowing as a way of term formation of Japanese literary terminology]. Visnyk Kyjivsjkogho nacionaljnogho universytetu imeni Tarasa Shevchenka: Skhidni movy ta literatury, 22, 6-9.

Asmukovych, I. V. (2014). Funkcionaljno-semantychni osoblyvosti anghlijsjkoji fakhovoji movy aviaciji [Functional and semantic features of the English professional language for aviation].

Atkins, P. (2013). The Word Monosugoshi and Changing Perceptions of Nature in Medieval Japan. Japanese Language and Literature, 47(2). http://www.aatj.org/journal-47-2

Danilenko, V. P. (1977). Russkaja terminologija: Opyt lingvisticheskogo opisanija [Russian terminology: Experience of linguistic description]. Nauka.

Debejko, O. V. (2006) Systema zhanriv klasychnoji japonsjkoji literatury [System of genres of classical Japanese literature]. Visnyk Kyjivsjkogho nacionaljnogho universytetu im. T. Shevchenka, 11, 36-41. 
Duda, O. I. (2015) Osoblyvosti funkcionuvannja kredytno-bankivsjkykh terminiv anghlijsjkoji movy u fakhovykh tekstakh [Features of the functioning of credit and banking terms in English in professional texts]. Naukovi vyklady, 1, 102-106.

Felber, H. (1980). International standardization of terminology. Standardization of Nomenclature:

Series "International Journal of Sociology of Language", 23, 71-77. Lybidj.

Ghalych, O. A., Nazarecj V. M., \& Vasyljjev Je. M. (2001). Teorija literatury [Theory of literature].

Ghrycaj, I. S. (2012) Vplyv kontekstu na pereklad terminiv u tvorakh khudozhnjoji literatury ta ZMI. [Influence of context on the translation of terms in works of fiction and mass media]. Naukovi zapysky / Nacionaljnyj universytet "Ostrozjka akademija", 25-28.

Halizev, V. E. (1986). Drama kak rod literatury [Drama as a genre of literature]. Izdatelstvo MGU.

Irwin, M. (2008). Homomorphemic Diffusion in Japanese Nonce Lexemes. Japanese Language and Literature, 42(1). http://www.aatj.org/journal-42-1

Jacenko, N. O. (2007) Nazvy vijsjkovoji formy odjaghu v ukrajinsjkij movi [Names of military uniforms in Ukrainian].

Khalinovsjka, L. A. (2003) Aviacijna leksyka v naukovo-fantastychnij literaturi [Aviation vocabulary in science fiction]. Kuljtura slova, 62, 51-55.

Komarnycjka, T. K. (2010). Strukturno-semantychni ta funkcionaljni osoblyvosti suchasnoji japonsjkoji jurydychnoji terminologhiji [Structural-semantic and functional features of modern Japanese legal terminology].

Kvitko, I. S., Lejchik, V. M., Kabancev, G. G. (1987). Terminovedcheskie problemy redaktirovanija [Terminological problems of editing]. Vyshha shkola.

Kyjak, T. R. (2009). Fakhovi movy jak novyj naprjam linghvistychnogho doslidzhennja [Professional languages as a new direction of linguistic research]. Inozemna filologhija, 121, 138-142.

Lamarre, T. (2013). The Pursuit of Harmony: Poetry and Power in Early Heian Japan. Japanese Language and Literature, 47(2). http://www.aatj.org/journal-47-2

Laukik, P. A., Rajat, P. (2015). Japanese Terminology Referred to Continuous Improvement, IJSRD International Journal for Scientific Research \& Development, 3(2). https://www.researchgate.net/publication/277572352_Kaizen_Its_Applications_-

_A_Japanese_Terminology_Referred_to_Continuous_Improvement

Lejchik, V. M. (2007) Terminovedenie: predmet, metody, struktura [Terminology: subject, methods, structure]. Izdatelstvo LKI.

Madzhaeva, S. I. (2011) Terminy v medicinskom diskurse [Terms in medical discourse]. Vestnik Cheljabinskogo gosudarstvennogo universiteta: Filologija. Iskusstvovedenie, 60 / 33(248), 92-94.

Masaoka, Shiki (2013). Khajdzhin Buson ("Poet khajku Buson") [Haijin Buson ("Haikai Poet Buson")]. Japonsjka poetyka: khrestomatija, 176-178.

Moretti, L. (2010). Kanazōshi Revisited: The Beginnings of Japanese Popular Literature in Print. Monumenta Nipponica, 65(2), 297-356. https://muse.jhu.edu/article/426304

Nikitina, S. E. (1987) Semanticheskij analiz jazyka nauki: Na materiale lingvistiki [Semantic analysis of the language of science: On the material of linguistics]. Nauka.

Selivanova, O. O. (2006) Suchasna linghvistyka: terminologhichna encyklopedija [Modern linguistics: terminological encyclopaedia]. Dovkillja-K.

Shatalina, O. F. (2009) Funkcionuvannja literaturoznavchoji terminologhiji u tvorakh I. Ja. Franka [Functioning of literary terminology in the works of I. Y. Franko]. Uchjonye zapiski Tavricheskogo nacional'nogo unstituta imeni V. I. Vernadskogo: Filologija. Socialnye kommunikacii, 22(61) / 3, 42-45.

Shevchenko, L. L. (2010) Motyvacijni osnovy ta bazovi modeli semantychnogho procesu terminologhizaciji [Motivational bases and basic models of the semantic process of terminology]. Movoznavstvo, 1, 76-85.

Soljanenko, O. L. (2017). Osoblyvosti tvorennja ta vzhyvannja abreviatur medychnoji terminologhiji $\mathrm{v}$ anghlomovnykh istorijakh khvorob [Formation and Usage Features of Medical Terminology Abbreviations in English Case Reports]. Naukovyj chasopys Nacionaljnogho pedaghoghichnogho universytetu imeni M. P Draghomanova: Serija 9. Suchasni tendenciji rozvytku mov, 16, 217-225.

Syndegha, R. Je., \& Ivashhyshyn O. M. (2009). Strukturni osoblyvosti ta funkcionuvannja terminiv v anghlomovnykh tekstakh z problem komp'juternykh nauk ta informacijnykh tekhnologhij [Structural features and functioning of terms in English texts on computer science and information technology issues] Naukovi zapysky: Serija "Filologhichna", 11, 351-357.

Vakulenko, M. O. (2013). Metodologhichni zasady vyvchennja naukovoji terminologhiji [Methodological principles of studying scientific terminology]. Terminologhichnyj visnyk, 2(2), 16-21. 
Zhanghazinova, R. T. (2014). Literaturoznavcha terminologhija pochatku XX st.: leksykosemantychnyj aspekt [Literary terminology of the early twentieth century: lexical and semantic aspect]. Naukovi praci, 221/209, 29-32.

柳田國男 (1941)。分類山村語量。東京: 国書刊行会。 [Janagida Kunio. Vocabulary of mountain villages (by topic). Tokyo].

\section{日本古典文学大辞典}

(1985)。編者：市古（いちこ）貞次（ていじ）。東京：岩波書店。[Large Dictionary of Ancient Japanese Literature / edited by Ichiko Teiji. Tokyo].

日本近代文学大事典（1978）。編者：小田切（おだぎり）進（す寸む）。東京：講談社。

[Large dictionary of modern Japanese literature / edited by Odagiri Susumu. Tokyo].

新潮日本文学辞典 (1988)。編者：磯田（いそだ）光一（こういち）。東京：新潮社。

[Dictionary of Japanese Literature Shincho / edited by Isoda Koichi, Tokyo].

日本文学辞典（1954)。編者：久松（ひさまつ）潜一（せんいち）。東京:

学生社。[Dictionary of Japanese Literature / edited by Hisamacu Sen'ichi, Tokyo].

\section{Sources of Illustrative Material:}

有賀長雄 (1889)。文学論。東京: 丸善商社書店。[Ariga Nagao. Literary theory. Tokyo, 1889].

後鳥羽 (1989)。新古今和歌集。真名序。日本古典文学全集。東京、巻き 50 。 [Go-Toba. Shin Kokin Wakashū. New collection of poems ancient and modern. Preface (Manajo). Complete collection of Japanese classical literature. Tokyo, 1989. Vol.50].

Tokyo, 2012].

伊藤整 (2012)。近代日本の文学史。東京: 夏葉社。[Itō Sei. Literature history of modern Japan.

紀淑望 (1971)。古今和歌集。真名序。日本古典文学全集。 東京：小学館。巻 7 。 $\mathrm{Ki}$ no Yoshimochi. Preface (Manajo). Kokin Wakashū. Collection of Japanese poems of ancient and modern times. Complete collection of Japanese classical literature. Tokyo, 1971, Vol. 7].

紀貫之 (1971)。古今和歌集。仮名序。日本古典文学全集。東京：小学館。巻 7 。 $[\mathrm{Ki}$ no

Tsurayuki. Preface (Kanajo). Kokin Wakashū. Collection of Japanese poems of ancient and modern times. Complete collection of Japanese classical literature. Tokyo, 1971. Vol. 7].

正岡子規 (2016)。芭蕉雑談。東京: 岩波書店。[Masaoka Shiki. Chat about Bashō. Tokyo, 2016]. 1993].

壬生忠罗 (1993)。和歌十種。東京。[Mibu no Tadamine. Ten styles of Japanese poems. Tokyo,

本居宣長。源氏物語玉の小櫛。[Motoori Norinaga. Jasper comb of “The Tale of Genji”]. http://archive.wul.waseda.ac.jp/kosho/bunko30/bunko30_a0168/bunko30_a0168.html

中村武羅夫 (2015)。本格小説と心境小説と文壇随筆。東京: 新潮社。 [Nakamura Murao. True prose and prose about the inner world. Tokyo, 2015].

種田山頭火。一草庵日記。[Taneda Santōka. Ikusa-an diary]. https://www.aozora.gr.jp/cards/000146/files/50413_40526.html

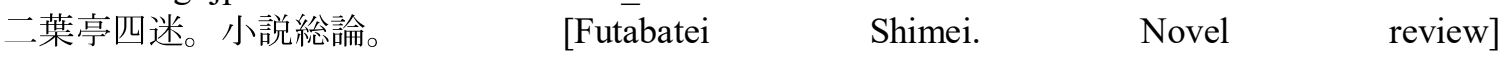

http://www.aozora.gr.jp/cards/000006/files/1868_22437.html 藤原良経

(1989)。新古今和歌集。仮名序。日本古典文学全集。東京:

小学館、巻 5 O。[Fujiwara no Yoshitsune. Shin Kokin Wakashū. New Collection of Poems Ancient and

Modern. Preface (Kanajo). Complete collection of Japanese classical literature. Tokyo, 1989. Vol.50].

藤原公任 (1978)。和歌九品。日本古典文学全集。東京: 小学館、巻 65 。 [Fujiwara no Kintō.

Nine degrees / skill / of Japanese poetry. Complete collection of Japanese classical literature. Tokyo, 1978. Vol. 65].

藤原公任 (1978)。新選髄脳。日本古典文学全集。東京: 小学館、巻 65 。[Fujiwara no Kintō.

Updated essence (poetry). Complete collection of Japanese classical literature. Tokyo, 1978. Vol. 65].

藤原定家 (1989)。近代秀歌。日本古典文学全集。東京：小学館、巻 50 。[Fujiwara no Teika.

Beautiful poems of the new era. Complete collection of Japanese classical literature. Tokyo, 1989. Vol. 50]. 坪内逍遥 (1963)。小説神髄。日本近代文学全集。東京。[Tsubouchi Shōyō. Essence of prose.

Complete collection of Japanese modern literature, Tokyo, 1963].

志賀直哉。リズム。 [Naoya Shiga. Rhythm]. http://seturi597.blog.fc2.com/blog-entry-61.html 


\section{Бібліографічний опис:}

Аністратенко, Л. С. (2020). Текстуальні особливості японської літературознавчої термінологї. Науковий часопис Національного педагогічного університету імені М. П. Арагоманова. Серія 9. Сучасні тенденцї розвитку мов, 20. 1632. https://doi.org/10.31392/NPU-nc.series9.2020.20.02

\section{Анотація}

У статті описано та систематизовано текстуальні особливості фахової мови японського літературознавства, репрезентованої у класичних японських літературознавчих трактатах. На матеріалі 17 трактатів виявлено кількісне співвідношення загальнолітературної лексики та літературознавчої термінологї̈ у фахових текстах японського літературознавства; встановлено відсоток надгалузевої, галузевої та міжгалузевої літературознавчої термінологї; виявлено $i$ проаналізовано стилістичні засоби, вжиті у текстах; здійснено порівняльний аналіз письмового дискурсу японського літературознавства в діахронії; виявлено специфічні риси текстів японського літературознавства.

За допомогою квантитативного методу встановлено, щяо співвідношення вживання літературознавчої термінологї до загальної кількості лексики в тексті не має чіткої градації у часі, а, скоріше, с виявом індивідуального стилю автора трактату. Середня термінологічна насиченість фахових текстів японського літературознавства складає 20\%. Такий показник уважається невисоким порівняно з показниками інших галузей.

Середній показник термінологічної насиченості текстів окремими аналізованими групами термінів, за результатами пропонованого дослідження, такий: загальнонаукова термінологія - 18\%, міжгалузева термінологія - 8\%, термінологія інших галузей - 8\%, надгалузева термінологія - 15\%, галузева термінологія - 51\%.

Також було обчислено відсоткові показники термінів різних галузей японського літературознавства, зокрема лірики, епосу, драми, ліро-епосу, ліро-драми, фольклору. Виявлено переважання термінологічних одиниць галузі лірики (62 \%). Значна насиченість літературознавчих трактатів термінами галузі лірики зумовлена, на нашу думку, тим фактом, щуо протягом століть усієї історії японської літератури саме лірика вважалася високим мистецтвом.

Ключові слова: японська літературознавча термінологія, міжгалузева термінологія, термінологія фахових текстів, галузева термінологія, загальнонаукова термінологія. 